\title{
The First Record of Paropta paradoxus (Herrich-Schäffer, 1851) (Lepidoptera: Cossidae) in Hatay Province of Turkey and Its External and Genital Morphology
}

\author{
Erol ATAY ${ }^{*} \quad$ Erdal SERTKAYA $^{2} \quad$ Mahmut TATLI $^{3}$

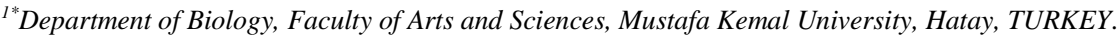 \\ ${ }^{2}$ Faculty of Agriculture, Dep. of Plant Protection, Mustafa Kemal University, Hatay, TURKEY. \\ ${ }^{3}$ Institute of Science, Mustafa Kemal University, Hatay, TURKEY.

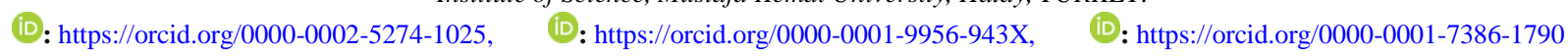

How to cite: Atay, E., Sertkaya, E. \& Tatl, M. (2019). The First Record of Paropta paradoxus (Herrich-Schäffer, 1851) (Lepidoptera: Cossidae) in Hatay Province of Turkey and Its External and Genital Morphology. Anatolian Env. and Anim. Sciences, 4(3), 525-531.

Atıf yapmak için: Atay, E., Sertkaya, E. \& Tatl, M. (2019). Hatay'da Paropta paradoxus (Herrich-Schäffer, 1851) (Lepidoptera: Cossidae)'un İlk Kaydı ve Türün Diş ve Genital Morfolojisi. Anadolu Çev. ve Hay. Dergisi, 4(3), 525-531.

\begin{abstract}
This study was conducted as field and laboratory studies. The grapevines that show sign of damage were collected from Reyhanlı and Kırıkhan districts in Hatay then brought to the laboratory. The larvae in the grapevine were obtained mature individuals by taking culture in the laboratory. A total of 3 male Paropta paradoxus (Cossidae) emerged from the pupa. Specimens were dissected in the laboratory and prepared male genitalia and wings slides. We described the external and male genital morphology of $P$. paradoxus in detail and also diagnostical morphological features. As a result of the study, P. paradoxus is first record for Hatay.
\end{abstract}

Keywords: Cossidae, Hatay, Lepidoptera, Paropta, Paropta paradoxus.

\section{Hatay'da Paropta paradoxus (Herrich-Schäffer, 1851) (Lepidoptera: Cossidae)'un İlk Kaydı ve Türün Dış ve Genital Morfolojisi}

Öz: Bu çalışma arazi ve laboratuvar çalışmaları şeklinde yürütülmüştür. Hatay'da Reyhanlı ve Kırıkhan ilçelerindeki üzüm (bağ) bahçelerinde zarar belirtisi gösteren asma dalları toplanarak laboratuvara getirilmiştir. Asma dalları içerisindeki larvalar laboratuvarda kültüre alınarak ergin bireyler elde edilmiştir. Toplam 3 adet erkek Paropta paradoxus (Cossidae) pupadan çıkmıştır. Örneklerden erkek genital organı ve ön ve arka kanat preparatları yapıldı. $P$. paradoxus'un dış morfolojisi ve erkek genital organları ayrıntılı olarak tanımlandı. Sonuç olarak, $P$. paradoxus türü Hatay için ilk kayıttır. 


\section{INTRODUCTION}

According to Schoorly (1990), the Cossidae Leach, 1815 [1830] is a cosmopolitan moth family with roughly seven hundred described species. According to Yakovlev et al (2015), with a global distribution, Cossidae comprise about 1000 known species, 800 of them being recorded from the old World. The english vernacular name for the family is Carpenter Moths, because of the larval habit of boring in plants, particularly trees. Nearly all species live as a larva in plants. Several species are known to cause serious damage to plants of economic importance. The adults of most species are nocturnal (Schoorly, 1990).

The genus was established for Cossus paradoxus Herrich-Schäffer, [1851], described from Smyrna [İzmir, Turkey] (Plaut, 1973; Yakovlev \& Witt, 2017). According to Schoorly (1990), Staudinger notes as characteristics of Paropta Staudinger, 1899 a rather strongly bipectinate male antenna and a shortly bipectinate female one. However, the male and female antenna of Paropta paradoxus are bipectinate, up to nearly rather strongly. The rami have approximate one rows of moderately long hairs on the inner margin and approximate one row of moderately long hairs on the outer margin.

Paropta paradoxus is a species of moth of the Cossidae family. Paropta paradoxus distributed from Asia Minor over Syria to Egypt, Saudi Arabia, Lebanon, Israel, Iran, Jordan, Cyprus and Rhodes (Schoorly, 1990; Yakovlev \& Witt, 2017). Host plants of species are Ficus carica, F. pseudosycomorus, Albizia lebbeck, Vitis vinifera (Schoorly, 1990; Yakovlev \& Witt, 2017), Acacia arabica, Cercis siliquastrum and Crataegus species (Yakovlev \& Witt, 2017).

Plaut (1973), gives the following information about the biology of $P$. paradoxus in the study that "On the biology of Paropta paradoxus (Lep., Cossidae) on grapevine in Israel": The biology of Paropta paradoxus, a new pest of the grapevine, was studied in field and laboratory during 19621972. Descriptions give the imago and developmental stages. The life-cycle is completed in 1-3 years. Adults are active during April-September and eclose mostly during the day with a male/female ratio of 0.65 (3.3 in UV lighttrapcatches). Light induces a deep torpor in most adults. After mating, which lasts 30-60 min, females lay up to 275 eggs in their life span of 1-14 days (males 2-13 days). In the vineyard eggs are glued under loose bark, in batches of 15.6 (1-63), and hatch in 20-32 days. The neonate larvae disperse and settle under loose bark where they begin feeding; penetration of the wood is mainly through dried stubs of pruned canes, and galleries are excavated along the axes of stems and branches. Larvae may also develop under dry bark. The pest overwinters as active immature larvae and diapausing mature, prepupal larvae. The pupa is usually formed in the larval galleries, and lasts 16-45 days. In heavily infested vines the pupae may be cannibalized by larvae; both larvae and pupae may be preyed on by woodpeckers.

There are 49 species (19 genera) belonging to the family Cossidae, and one species belonging to the genus Paropta Staudinger, 1899 in Turkey (Koçak \& Kemal, 2018). Koçak and Kemal $(2006 ; 2007)$ listed the first attempt on the checklist of the Turkish moths. Totally, 4604 moth species were listed together with their synonymous named and updated provincial distributions. Later, the authors (Koçak \& Kemal, 2018), reported that the Turkey Lepidoptera fauna was 5577 (butterfly: 220 genera, 412 species; moth: 1621 genera, 5164 species) species belonging to 76 families ( 9 butterfly, 67 moth families). In addition, the same authors listed 772 lepidoptera species, 638 Heterocera and 134 Rhopalocera, belonging to the province of Hatay. Atahan et al., (2018) reported the number of species as 162 butterfly in Hatay.

As a result of the study, Paropta paradoxus (Herrich-Schäffer, 1851) is first record for Hatay.

\section{MATERIAL and METHODS}

This study was conducted as field and laboratory studies.

Field Studies: Field studies were carried out in the vineyard orchards in Reyhanl1 and Kırıkhan districts of Hatay. The trees in the grape orchards were individually checked and vine branches were collected that showing signs of damage. These vine branches, which are supposed to contain larvae, brought to the laboratory and cultured, then adult individuals obtained. A total of 3 male Paropta paradoxus (Cossidae) emerged from the pupa.

Laboratory Studies: Before losing body water, specimens were sorted according to body sizes, and were needed with a number 2 insect needles that matched the size of the custom sized boards, strain and inhibition couples were strained in laboratory work. For the drying of the stretched specimens, they were kept at room temperature for two weeks in a dark and dry place. Male genital organ was prepared for the identification of the species following morphological examinations and measurements on the male specimens. The needling of the moths, stretching of the wings and genital organ preparations were done accordingly the methods that defined in Atay's work (2006). The major taxonomic characters of species described. Important morphological organs of Paropta paradoxus photographed and drawn. The specimens stored at the Biology Department of Mustafa Kemal University in Hatay.

\section{RESULTS}

Genus Paropta Staudinger, 1899 (Lepidoptera: Cossidae) 
Syn: Alcterogystia Schoorl, 1990 (Yakovlev \& Witt, 2017; Koçak \& Kemal, 2018) (Cossidae)

Paropta paradoxus Herrich-Schäffer, (1851),

Syn: Cossus l-nigrum Bethune-Baker, 1894; Paropta pharaonis Bang-Haas, 1910 (Yakovlev \& Witt, 2017; Koçak \& Kemal, 2018)

The distribution in Turkey: Mersin and İzmir (Koçak \& Kemal, 2018).

The distribution in the World: Cyprus, Greece, Liberia, Israel, Iran, Syria, Egypt (Plaut, 1973; Karsholt \& Razowski, 1996; Koçak \& Kemal, 2018).

Material Examined: Reyhanl1-Hatay: $36^{\circ} 16^{\prime} 39^{\prime \prime} \mathrm{N}$; 36³4'53" E, 125 m.; 14.VIII.2019 10.

Kurıkhan-Hatay: $\left(36^{\circ} 07^{\prime} 26^{\prime \prime} \mathrm{N} ; 36^{\circ} 08^{\prime} 39^{\prime \prime}\right.$ E， 350 m.); 22.VIII.2019 20ิ.

Description and Measurements: Male (Figure 1): Length of forewing $16 \mathrm{~mm}$; wingspan $34 \mathrm{~mm}(35-33 \mathrm{~mm})$; body length $18 \mathrm{~mm}$. On the head, vertex and frons covered with greyish brown hairs. Antenna strongly bipectinate with scales along the dorsal surface, and with 54-65 flagellomeres. Its length $8,6 \mathrm{~mm}$., and its length 0,55 times longer than forewing length. Labial palpus well developed, long, strongly recurved upwards and extends to the front end of the eye. Its second segment is the longest and widest one, and third segment is the smallest. All segments of labial palpus covered with greyish brown hairs. Eyes with dark brown are very large and well developed. Haustellum is absent. On the head, ocelli and chaetosemata are absent. Head is 1,27 times wider than its height (Figures 2, 3).

Thorax and abdomen covered with greyish light brown scales.

Forewings are long and wide; forewing length is 2,44 times longer than its width. The upper surface of the forewings; with greyish light brown scales. There are noticeable thin and dark patterns on the postdiscal region of the forewing. Fringe is very short and brown.

Hindwings are broad and its length 1,40 times longer than its width. The upper surface of the hindwings are completely with greyish black. Fringe is very short and light brown.

The male genital organ is as Figures 4, 5 .

Uncus long, with beak like on apex. Gnathos medium length; its arms thine and narrow, densely covered with fine spikes. Valva long, apex wide rounded; covered short and thin hairs; its length about 3 times longer than its width. There is a small serrate structure on the costal edge of the valva. Transtilla is strongly sclerotised, and hook like curved, gradually tapering to apex from a wide base. Sacculus is wide at the base. Juxta small. Saccus is short and wide; slightly rounded. Aedeagus is long and narrow, its length 11,5 times longer than its width; slightly curved throughout its length, and without corniti.
Veins of forewing and hindwing are drawn (Figure

$6)$.

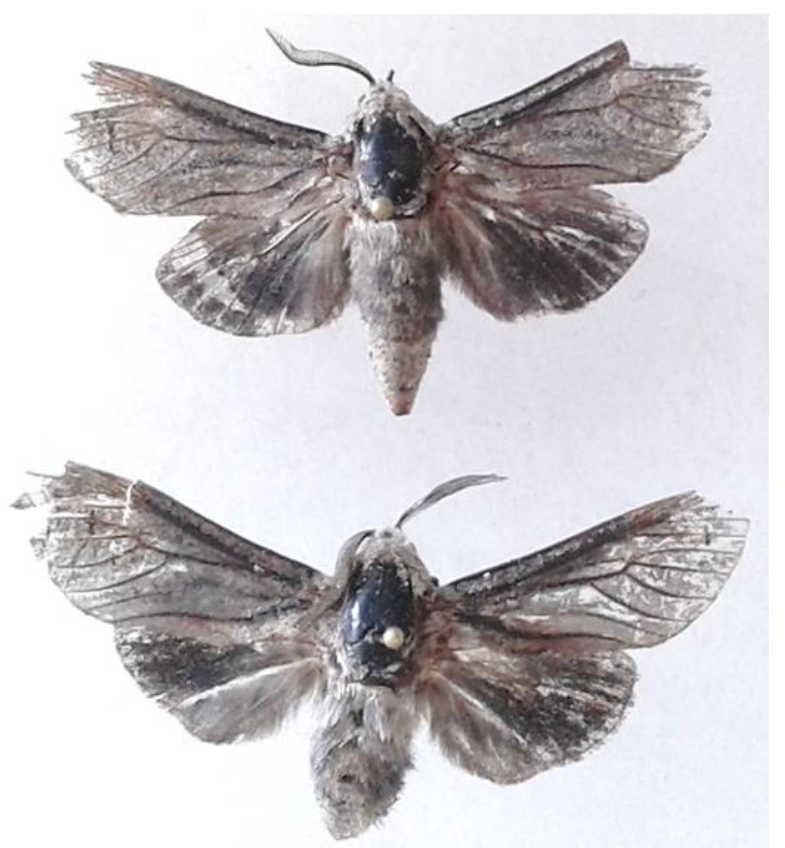

Figure 1. Adults of Paropta paradoxus (Cossidae).

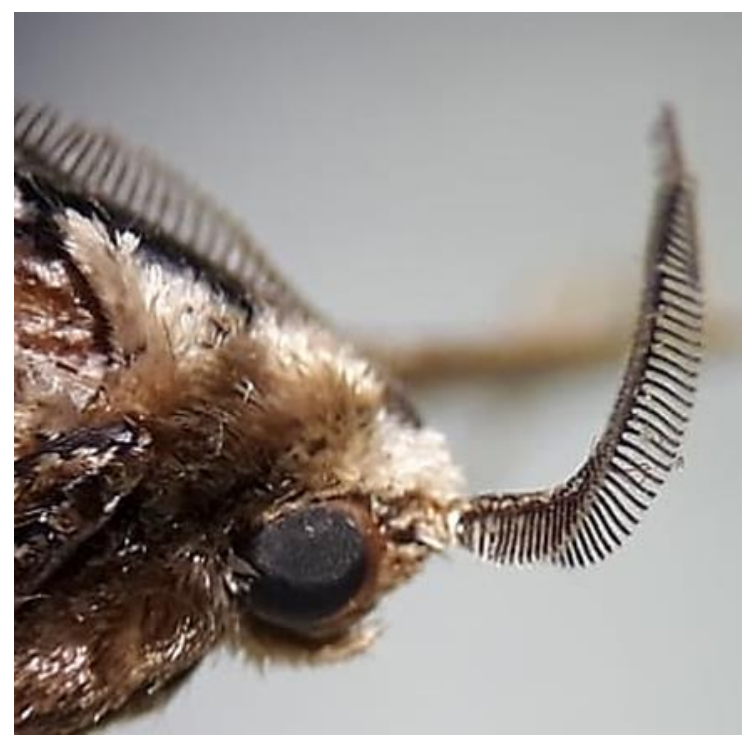

Figure 2. The head structure of Paropta paradoxus, (Lateral View).

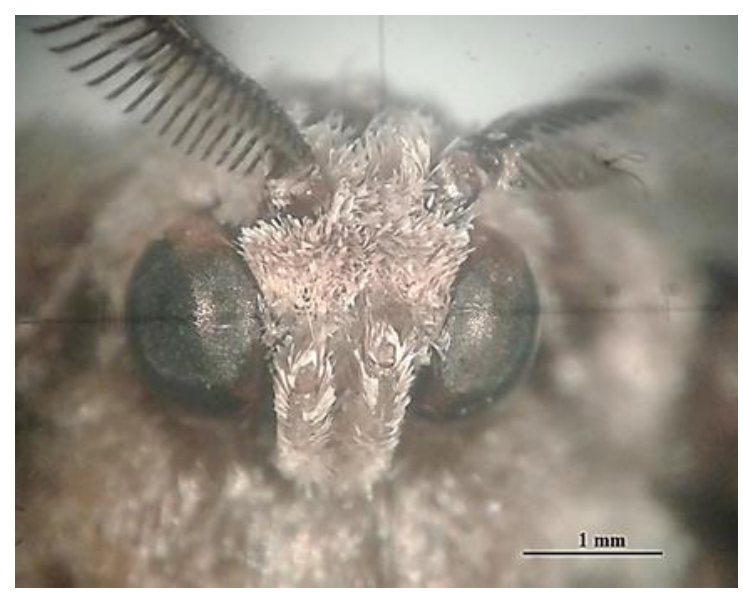

Figure 3. The head structure of Paropta paradoxus, (front View). 


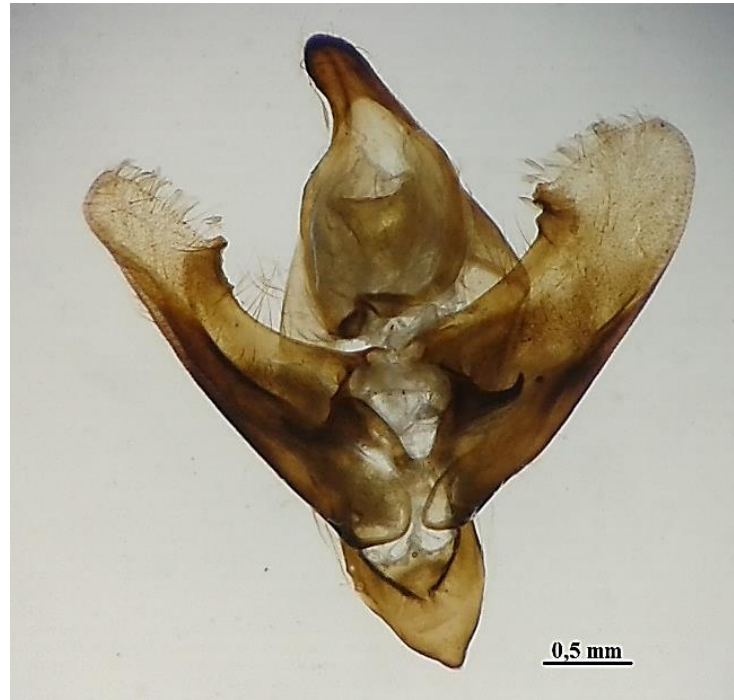

Figure 4. The Male Genitaliae of Paropta paradoxus (General Structure).

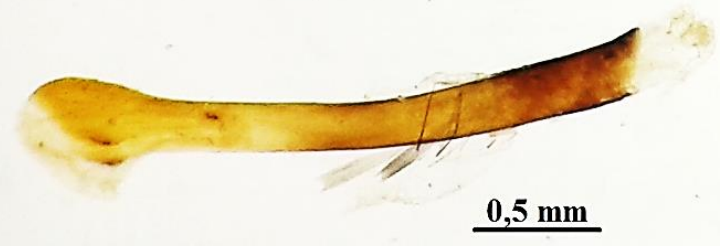

Figure 5. The Male Genitaliae of Paropta paradoxus (Aedeagus).
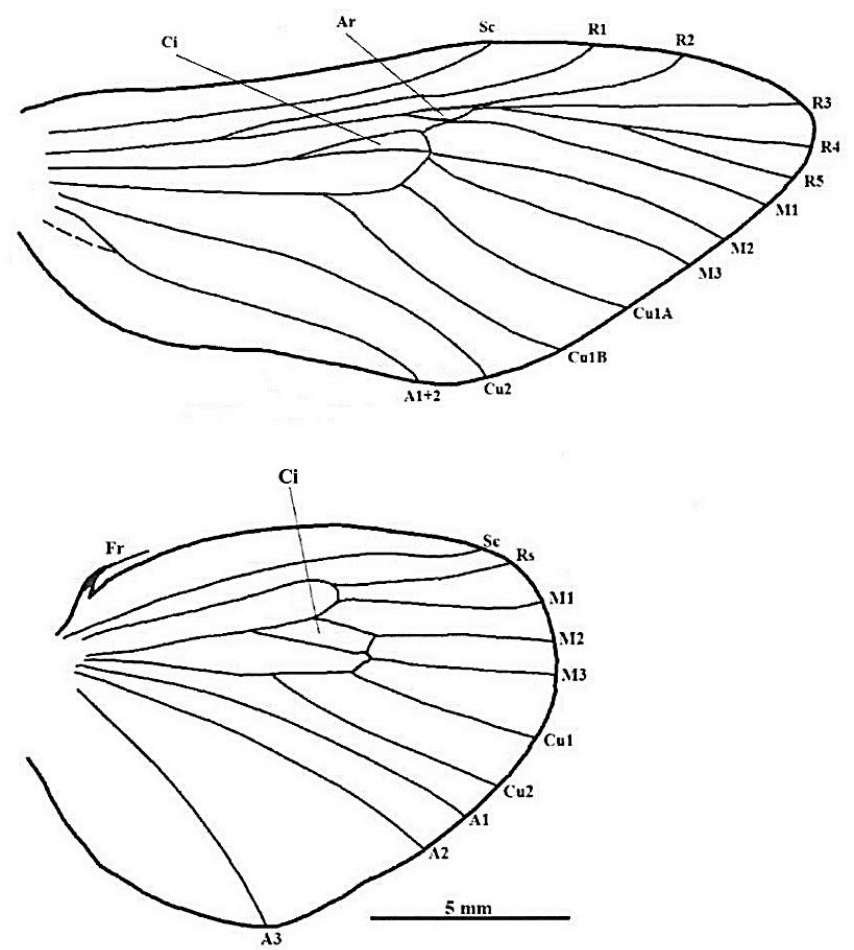

Figure 6. Veins of forewing and hindwing of Paropta paradoxus (Ar: areola, $\mathrm{Ci}$ : cellula intrusa)

In this study, we described the external and the male genital morphology of Paropta paradoxus. The important taxonomic characters belong to them were redescribed in detail by comparison of different parameters with each other. The external and genital taxonomic characters were measured with digital caliper and sterio microscope. In addition, larvae and damage photos of the species are given in the study Figures 7, 8).

Paropta paradoxus is new record for the the lepidoptera fauna of Hatay.

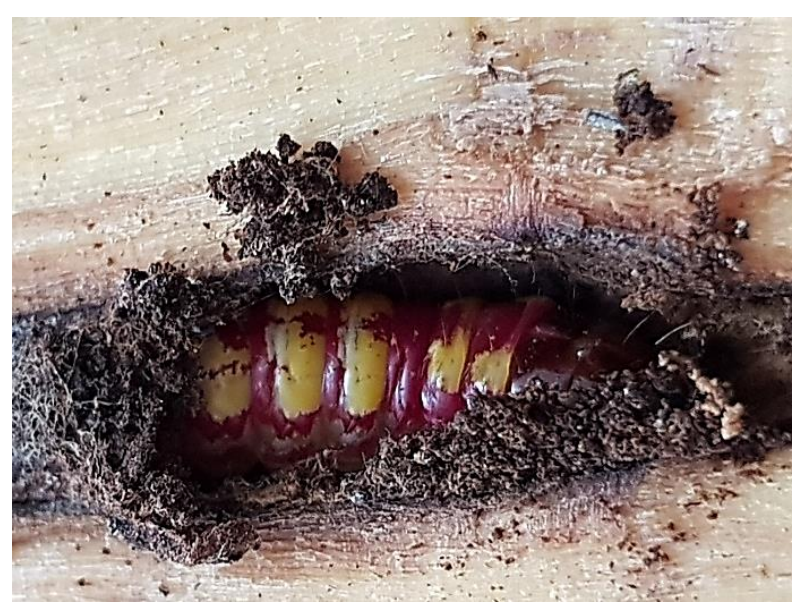

Figure 7. The Larvae of Paropta paradoxus.
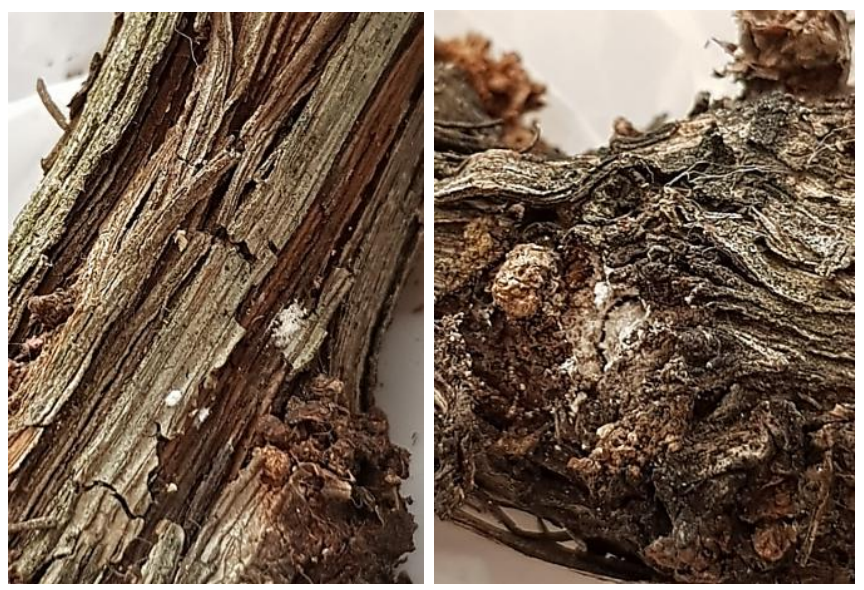

Figure 8. Vine branches showing signs of damage.

\section{REFERENCES}

Atahan, A., Atahan, G., Gül, M. \& Atahan, M. (2018). Hatay'ın kelebekleri. 72 Tasarım Ltd. Şti. Ankara, TR, 179p.

Atay, E. (2006). The identity of Parapoynx affinialis (Guenee, 1854) (Lepidoptera, Crambidae, Nymphulinae) in Turkey. Journal of Entomology, 3(1), 76-81.

Karsholt, O. \& Razowski, J. (1996). The lepidoptera of Europe a distributional checklist. Apollo Books, Denmark, 380p.

Koçak, A.Ö. \& Kemal, M. (2006). Checklist of the Lepidoptera of Turkey. Centre for Entomological Studies, Priamus Suppl. 1, 1-196.

Koçak, A.Ö. \& Kemal, M. (2007). Revised and annotated checklist of the Lepidoptera of Turkey. Centre for Entomological Studies, Priamus Suppl. 8, 1-150. 
Koçak, A.Ö. \& Kemal, M. (2018). A synonymous and distributional list of the species of the Lepidoptera of Turkey. Centre for Entomological Studies, Priamus Suppl. 8, 1-489.

Plaut, H.N. (1973). On the biology of Paropta paradoxus (H.-S.) (Lep., Cossidae) on Grapevine in Israel. Bull. Ent. Res., 63, 237-245.

Schoorl, J.W. (1990). A phylogenetic study on Cossidae (Lepidoptera: Ditrysia) based on external adult morphology. Zoologische Verhandelingen, 263, 3295.

Yakovlev, R.V. \& Witt, T.J. (2017). Taxonomic Notes About Paropta Staudinger, 1899 (Lepidoptera: Cossidae). Zoology in the Middle East, 63, 166-171.
Yakovlev, R.V., Poltavsky, A.N., Ilyina, E.V., Shchurov, V.I. \& Witt, T.J. (2015). Cossidae (Lepidoptera) of the Russian Caucasus with the Description of a New Species. Zootaxa, 2, 270-288.

\section{*Corresponding author's:}

Erol ATAY

Department of Biology, Faculty of Arts and Sciences, Mustafa Kemal University, Hatay, TURKEY.

E-mail : eatay@mku.edu.tr

ORCID : https://orcid.org/0000-0002-5274-1025 